\title{
SERUM DEPRIVATION INDUCES APOPTOTIC CELL DEATH IN THE THESC CELL LINE
}

Ana Petrovic, Ivana Nikolic ${ }^{\mathrm{a}}$, Milan Zaric ${ }^{\mathrm{a}}$, Ivanka Zelen ${ }^{\mathrm{a}}$, Danijela Jovanovic ${ }^{\mathrm{b}}$, Zoran Milosavljevic ${ }^{\mathrm{c}}$, Tatjana Kastratovic ${ }^{\mathrm{d}}$, Maja Colic $^{\mathrm{e}}$ and Marina Mitrovic ${ }^{\mathrm{a}}$ a) University of Kragujevac, Faculty of Medical Sciences Kragujevac, Department of Biochemistry

b) Clinical Centre Kragujevac, Haematology Department

c) University of Kragujevac, Faculty of Medical Sciences Kragujevac, Department of Histology and Embryology

d) Clinical Centre Kragujevac, Gynaecology and Obstetric Department

e) University of Kragujevac, Faculty of Medical Sciences Kragujevac, Department of Physiology

SERUMSIKA DEPRIVACIJA INDUKUJE ĆELIJSIKU SMRT

APOPTOZOM U THESC ĆELIJSKOJ LINIJI

Ana Petrović, Ivana Nikolića, Milan Zarića, Ivanka Zelenª, Danijela Jovanovićb, Zoran Milosavljevićc, Tatjana Kastratovićd, Maja Č́liće i Marina Mitrovića

a) Univerzitet u Kragujevcu, Fakultet medicinskih nauka Kragujevac, katedra Biohemije

b) Klinički centar Kragujevac, Centar za Hematologiju

c) Univerzitet u Kragujevcu, Fakultet medicinskih nauka Kragujevac, katedra Histologije sa embriologijom

d) Klinički centar Kragujevac, Klinika za ginekologiju i akušerstvo

Univerzitet u Kragujevcu, Fakultet medicinskih nauka Kragujevac, katedra Fiziologije

Received / Primljen: 7.05.2012.

Accepted / Prihvaćen: 1.03.2013.

\section{ABSTRACT}

Uterine myomas are comprised of smooth muscle cells from blood vessel walls of the uterus and fibroblasts, and constitute the basic components of fibroids. The aim of our study was to evaluate the cytotoxic and apoptotic effects of serum deprivation on fibroblasts originating from the ThESC myoma cell line. Cell viability, morphological changes and the percentage of apoptotic cells were determined in the presence and absence of serum. The experimental group was cultured in medium lacking serum for 24- and 48-hour periods, and the control group was cultured in complete medium. Cell viability was evaluated using the MTT assay. Changes in cell morphology were investigated using native microscopy. The percentage of apoptotic cells was determined using ethidium bromide/acridine orange staining. There was a time-dependent and statistically significant decrease in cell viability in the experimental group when compared to the control group. Cells in the experimental group displayed morphological changes that are characteristic of apoptosis. These changes were not detected in the control group. In the experimental group, there was a statistically significant increase in the percentage of apoptotic cells, while this percentage was not statistically significant in the control group. The obtained results suggest that the timeduration of serum deprivation directly correlates to the induction of apoptosis in the ThESC cell line.

Key words: fibroma, apoptosis, serum deprivation, viability

\section{SAŽETAK}

Miomi uterusa izgradeni su od glatkih mišićnih ćelija zidova krvnih sudova uterusa i fibroblasta koji sačinjavaju osnovnu komponentu fibroida. Cilj našeg istraživanja bilo je ispitivanje citotoksičnog $i$ apototičnog efekta serumske deprivacije na fibroblaste koji vode poreklo iz mioma, ThESC ćelijska linija. Vijabilnost ćelija, morfološke promene kao i procenat apoptotičnih ćelija određivani su u prisustvu $i$ odsustvu seruma. Eksperimentalna grupa ćelija bila je uzgajana u medijumu koji nije sadržao serum u toku $24 i$ 48 časova, dok je kontrolna grupa ćelija uzgajana u kompletnom medijumu. Vijabilnost ćelija bila je odredivana pomoću MTT testa; morfološke promene detektovane su pomoću nativne mikroskopije dok je procenat apoptotičnih ćelija bio određen bojenjem pomoću etidijum bromid/akril oranžom. Primećeno je statistički značajano smanjenje vijabilnosit ćelija eksperimentalne grupe u poređenju sa kontronom grupom ćelija. Ćelije eksperimentalne grupe pokazivale su morfološke promene karakteristične za apotozu. Ove promene nisu detektovane u kontrolnoj grupi ćelija. Statistički značajno povećanje u procentu apoptotičnih ćelija primećeno je u eksperimentalnoj grupi, dok u kontrolnoj grupi procenat apoptotičnih ćelija nije ispoljavao statističku značajnost. Dobijeni rezultati ukazuju da je dužina serumske deprivacije u direktnoj korelaciji sa indukcijom apoptotične smrti u ThESC ćelijskoj liniji.

Ključne reči: fibroidi, apoptoza, serumska deprivacija, vijabilnost
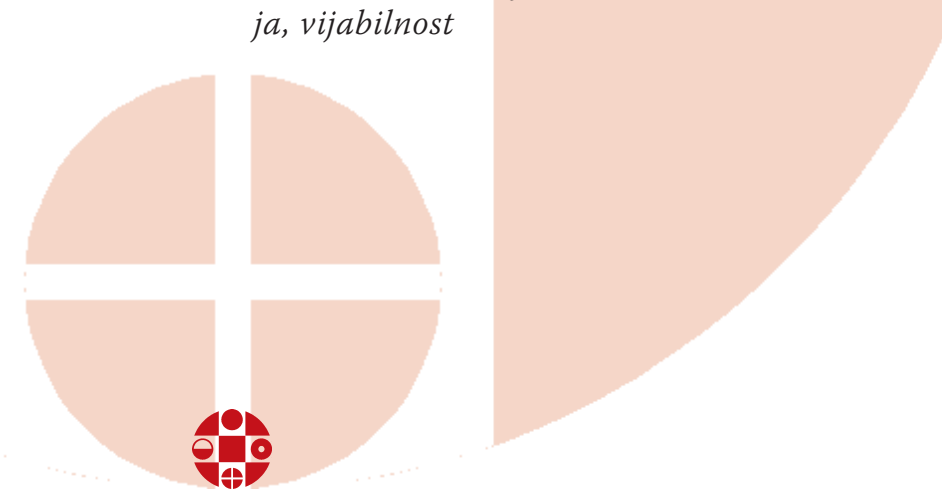

UDK: 618.14-006.36 / Ser J Exp Clin Res 2013; 14 (1): 23-28 DOI: 10.5937/SJECR14-1912 


\section{INTRODUCTION}

Uterine fibroids (myomas) are the most common pelvic tumours in women and the most common indication for hysterectomy. They occur primarily during the reproductive years (1). Fibroids are benign tumours that develop within the walls of uterine blood vessels and consist of smooth muscle cells and fibrous connective tissue (2). Their size varies from tiny nodules of approximately 10 $\mathrm{mm}$ to large tumours of greater than $20 \mathrm{~cm}$. Fibroids can be found protruding into the uterine cavity (submucosal), within the uterine wall (intramural), beneath the uterine serosa (subserosal), a nd, in rare instances, attached to abdominopelvic structures (parasitic) (3). Symptoms caused by fibroids include prolonged or heavy menstrual bleeding, pelvic pressure or pain, and, in rare cases, reproductive dysfunction (4). This is the most common gynaecological problem experienced by women, with clinical significance in $20-40 \%$ of women of childbearing age (2). Fibroid growth primarily depends on the hormone state of the organism. The ovarian steroid hormones oestrogen and progesterone stimulate fibroid growth (5). Other studies pinpoint diet, stress and ecological factors as significant in the aetiology of these tumours $(6,7)$. Fibroids are composed of smooth muscle cells and fibroblasts, which, according to some authors, originate from myometrial cells undergoing mitotic changes. As a result of these changes and myofibroblast formation, both oestrogen and progesterone have proliferation effects on these cells after binding to their receptors. The ThESC cell line is a human endometrium fibroblast-like cell (HESC) line obtained from an endometrial myoma that was immortalised with human telomerase reverse transcriptase (hTERT). Telomerase is an enzyme shown to confer unlimited replicative capacity to normal cells without causing the deregulation of normal growth control. The immortalised HESC line (ThESC) is karyotypically, morphologically, and phenotypically similar to the primary parent cells, and it is a powerful and consistent resource for in vitro research (8). The ThESC cell line is cultivated in basal growth medium supplemented with foetal bovine serum (FBS), which is also referred to as foetal calf serum (FCS). Serum provides a broad spectrum of macromolecules necessary for in vitro cell growth, such as glucose, albumin and other energy molecules. FBS is a very complex mixture of a large number of constituents, such as growth factors, hormones, lipoid substances, carrier proteins, and attachment and spreading factors (9). Compared to plasma, FBS shows a better mytogenic effect (stimulation of proliferation) because it contains growth factors referred to as insulin-like growth factor I (IGF-I) and insulin-like growth factor II (IGF-II) (10). Lipoids are essential for cell growth. Also present in FBS are cholesterol, fatty acids, phospholipids and triacylglycerols. The maintenance of normal processes involved in cell proliferation, maturation and differentiation requires the presence of hormones found in FBS, such as insulin, cortisone, triiodthyronine, thyroxine and PTH (9). Proteins found in serum, including vitronectin and fibronectin-like molecules, have important roles in cell attachment and cell adhesion (11). I $\alpha$-I is a serum protein that stabilises the cumulus extracellular matrix (12). Serum also provides beneficial factors to the culture environment, including energy substrates, vitamins, amino acids, and binding and transport proteins $(13,14)$. In addition to the above-mentioned functions, serum is important for the early expression of some genes encoding regulatory proteins, and serum components are known to activate protein kinase $\mathrm{C}(\mathrm{PKC})(15,16)$. Serum also enables the maintenance of optimal $\mathrm{pH}$ and the elimination of the toxic products from the medium (9). Serum deprivation is one of many methods used to induce programmed cell death, or apoptosis $(17,18,19)$. Previous research has demonstrated that cells in serum-deprived media undergo numerous changes that lead to apoptosis. After 2 hours of serum deprivation, some cultures show a retraction of the cytoskeleton, the rounding of cells, and the compaction of nuclear chromatin along the nuclear periphery (20). All of these morphological changes can be observed in cells in the very early stages of apoptosis. Serum depletion has a time-dependent effect on the number of apoptotic cells $(20,21)$. Morphological changes occur in the entire cell, and the dynamics of both protein synthesis and degradation change (22). As the protein dynamics change, so do the dynamics of DNA synthesis and degradation. Further serum deprivation results both in DNA fragmentation and slower DNA synthesis. Changes in the genetic material cause a decrease in the mitotic potential of serum-deprived cells. Short periods of 24 hours of serum deprivation significantly decrease the proportion of cells in mitosis, and after $48 \mathrm{~h}$ of serum deprivation, only $2 \%$ of cells are able to undergo mitosis (23). Prolonged treatment with serum-deprived medium induces massive DNA fragmentation in cells, which results in decreased viability in culture $(24,25,26)$. All of the described changes that occur in the absence of serum are hallmarks of apoptosis. Prolonged serum deprivation finally results in programmed cell death. Apoptosis in treated samples is significantly higher when compared to control cells cultivated in serum-supplemented medium. The percentage of apoptotic cells depends on the cell culture, type of serum, and volume of serum in the medium. However, most studies indicate that apoptosis is enhanced 2 to 8 times in serum-deprived cells. After $24 \mathrm{~h}$ of treatment, the percentage of apoptosis is 5 times higher when compared to the number of spontaneous apoptotic cells in the control group, while the ratio in the cells treated for 48 hours is 8 times higher when compared to control cells. The data demonstrate that the percentage of apoptosis induced by serum deprivation is time-dependent. To date, studies have shown that serum deprivation induces apoptosis in a caspase-dependent manner $(17,18$, $21,26,27)$. 


\section{MATERIALS AND METHODS}

In our experiments, we used the ThESC cell line (ATCC : CRL-4003tm) of human fibroblasts derived from a uterine myoma that have been immortalised with human telomerase reverse transcriptase (hTERT). The cells were cultured and maintained in DMEM complete growing medium containing $4.5 \mathrm{~g} / \mathrm{L}$ of glucose, $2 \% \mathrm{~L}$-glutamine $(2 \mathrm{mM}), 1 \%$ penicillin/ streptomycin, $1 \%$ non-essential amino acids, $1 \%$ insulin transferrin supplement and $10 \%$ FBS in a controlled environment at $37^{\circ} \mathrm{C}$ and $5 \% \mathrm{CO}_{2}$. Cells were washed three times in $1 \times \mathrm{PBS}$ before treatment. The cells were divided into two groups: the experimental group (FBS-deprived DMEM medium) and the control group (complete DMEM medium). The experimental group was treated with serum-deprived medium for 24 and $48 \mathrm{~h}$ and was then assayed using the MTT viability test and acridine orange/ethidium bromide staining. The MTT assay was used to determine the effect of serum starvation on the viability of experimental cells in comparison to the control cells. The percentage of viable cells in the experimental group was calculated in comparison to the viable cells in control group. To evaluate changes in morphology, cells were examined using phase-contrast microscopy following serum starvation for 24 and $48 \mathrm{~h}$. To visualise early and late apoptotic changes, the staining procedure for both control and treated cells was performed using both $0.01 \%$ acridine orange and ethidium bromide. The aim of our study was to investigate the effect of serum starvation on the viability of the human uterine myoma cells in vitro and its potential role in apoptosis.

\section{RESULTS}

We used the MTT assay to evaluate the effect of serum deprivation on the viability of ThESC cells. After treatment, the percentage of viable cells in the treatment group was calculated in comparison to the control group. Our results show that the serum-starved cells experienced a time-dependent and statistically significant decrease in viability when compared to the untreated cells. Furthermore, our results show a 9 times greater percentage of viable cells in the group of cells that were serumstarved for $24 \mathrm{~h}$ compared to the group that was serum-starved for $48 \mathrm{~h}$ (Figure 1.). This result correlates to the literature findings in which serum provides a broad spectrum of molecules necessary for the in vitro growth of cells (9).

1.

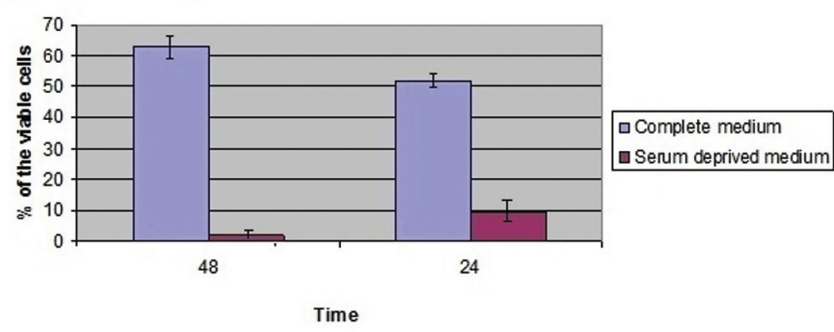

Figure 1. The percentage of viable ThESC cells after 24 - and 48-h periods of serum starvation compared to the control cells.
Following the MTT assay, phase-contrast microscopy was performed to determine the morphological changes that occurred in serum-starved cells. Data presented in the literature demonstrates that serum is crucial for cell attachment and cell adhesion (11) and that the I $\alpha$-I protein present in serum stabilises the cumulus extracellular matrix (12). These data suggest that serum provides molecules that are essential for maintaining normal cell morphology. To compare our findings to the available literature data, the morphological changes of ThESC cells were evaluated after serum deprivation (Figure 2.). Our results show that the morphological changes after serum-deprivation corresponded to the literature results and our MTT assay results. Control cells maintained normal morphology, including a normal nuclear shape and the appearance of the cytoplasmic skeleton. Control cells exhibited normal and undisrupted continuity of all features, including the integrity of the cell membrane, actin filaments, and the shape of the nuclear membrane,. Following $24 \mathrm{~h}$ of serum deprivation, cell morphology was slightly altered when compared to the control cells. Both the shape of the nucleus and the continuity of the cytoskeleton were different in the absence of FBS in the growth medium (Figure 2.). Chromatin condensation and disruption in normal cell morphology were obvious. After $48 \mathrm{~h}$ of serum starvation, the cells exhibited distinct morphological changes that clearly affected the nucleus, including both chromosomal defragmentation and nuclear shrinkage. The changes in cell morphology corresponded to the time of serum deprivation. The described changes are clear indicators of on-going apoptotic changes in the serum-deprived cells (Figure 2.).
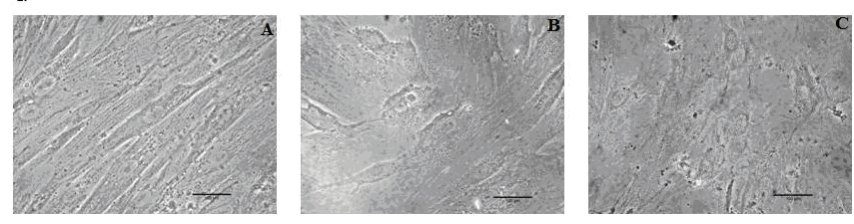

Figure 2. Morphological changes of ThESC cells following both 24- and 48-h periods of serum starvation. A. Normal morphology of control cells grown in complete medium. B. Partially disrupted morphology of cells grown in serum-deprived conditions after 24 hours. C. Completely disrupted cell morphology of the experimental group after 48 hours of serum deprivation.

We wanted to further analyse if the results obtained using the MTT assay and the observed morphological changes corresponded to the apoptotic changes as determined using ethidium bromide-acridine orange staining (Figure 3.). Ethidium bromide is used to identify cells that are in the final stages of apoptosis. To determine which of the treated cells exhibited early or late apoptotic changes, ethidium bromide-acridine orange staining was performed. The EB/AO combined stain causes live cells to fluoresce green, while apoptotic cells display distinctive red-orange fluorescence. The control cells (24 and $48 \mathrm{~h}$ ) displayed clear green fluorescence, which confirmed their viability. However, treated cells displayed fluorescence that ranged from light orange $(24 \mathrm{~h})$ to intense red $(48 \mathrm{~h})$. These results correspond to the previously described early and late apoptotic changes (Figure 3.). 

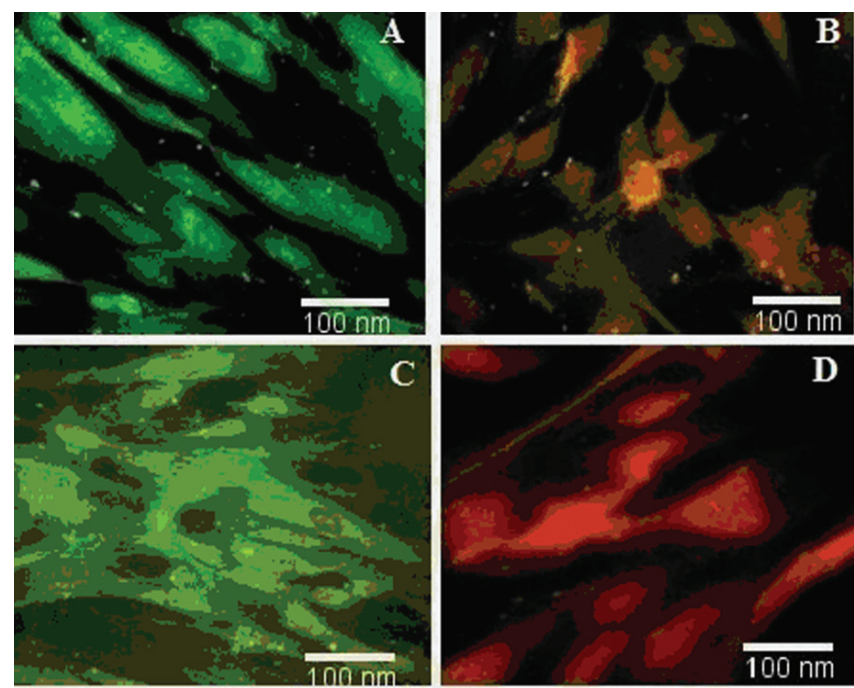

Figure 3. Morphological changes in ThESC cells were visualised using $0.01 \%$ acridine orange and ethidium bromide staining. A. Control cells grown in complete medium for $24 \mathrm{~h}$. B. Morphological changes of cells after $24 \mathrm{~h}$ of serum starvation. The arrows indicate defragmented DNA and a complete loss of normal morphology. C. Control cells grown in complete medium for $48 \mathrm{~h}$. D. Morphological changes of cells after $48 \mathrm{~h}$ of serum starvation, showing complete degradation of the nucleus. The observed morphological changes correspond to the typical changes for cells undergoing the late stages of apoptosis.

\section{DISCUSSION}

In the present study, we evaluated the effect of serum deprivation in a cultured human endometrium fibroblast-like cell line that was obtained from an endometrial myoma and immortalised with human telomerase reverse transcriptase. Serum provides viability for cells in culture due to the presence of tropic factors. In accordance with previous studies $(12,13,20,21,23)$, our results showed a large increase in the number of apoptotic cells after serum deprivation for both 24 and 48 hours when compared to untreated cells that were grown in medium supplemented with FBS. First, we investigated the influence of serum starvation on cultured ThESC cells using the MTT assay. Our results clearly suggest that serum-starved cells displayed a decrease in viability compared to untreated cells. The decrease in viability of serumstarved cells occurred in a time-dependent manner. These findings correlate to those obtained in other studies $(21,28)$ and confirm our hypothesis that serum provides a broad spectrum of molecules necessary for the in vitro growth of cells. The decrease in the number of viable cells was much larger after $48 \mathrm{~h}$. The number of the viable cells was reduced by five times after the first 24 hours and by nine times after the next 24 hours of treatment. This result suggests that cells undergo apoptosis more frequently after serum starvation for longer than 24 hours than when they are serum-starved for less than 24 hours. These results also indicate that approximately $10 \%$ of cells can overcome serum withdrawal for 24 hours but that a much smaller number of cells can overcome prolonged starvation. As trophic factor deficiency $(29,30,31)$ is known to induce apoptosis, we analysed cell morphology using phase-contrast microscopy. The phasecontrast microscopy results correlated with literature data $(12,13,20,21,23)$ and the results we obtained using the MTT assay. Images taken after 24 hours of serum starvation showed a significant number of deformed cells with membrane shrinkage and differences in chromatin condensation . The loss in the normal shape of the cells indicated that the cytoskeleton was also interrupted and that actin filaments had lost their structure and function. Some cells had almost normal shapes, which indicated that they still had not undergone apoptosis. Their nuclei were condensed, but mostly without shrinkage of the nuclear membrane. After $48 \mathrm{~h}$ of treatment, cells displayed a total loss of structure and membrane continuity. The chromatin was more condensed, and products of defragmentation were observed. Additionally, nuclei were smaller after $48 \mathrm{hr}$ of treatment when compared tothan after $24 \mathrm{~h}$ of treatment. Cells did not have distinct shapes, which indicated a total loss of cytoskeletal structures. We concluded that after $24 \mathrm{~h}$ of serum starvation, cells lose their membrane integrity but mostly keep their nuclear shape, while after 48 hours of starvation, most cells lose both membrane and nuclear integrity. Our results correlate with the results of previous studies $(20,32)$. The MTT assay and phase-contrast microscopy demonstrated that ThESC cells undergo apoptosis after serum starvation. Our next step was to confirm the viability of these cells by using staining to differentiate viable cells from apoptotic cells. To confirm our hypothesis and visualise the early and late apoptotic changes, we used an acridine orange/ ethidium bromide staining procedure. We used ethidium bromide/acridine orange viable staining, which causes live cells to fluoresce green and dead cells to fluoresce orange to red. The shade of red fluorescence depends on the apoptotic phase of the cell. Green fluorescence of control cells indicates that cells in the untreated control group are viable. Cells that had been treated for $24 \mathrm{~h}$ fluoresced light red, which indicated that these cells were in an early phase of apoptosis. Dark red fluorescence in cells that had been treated for $48 \mathrm{~h}$ indicated that these cells were in a late phase of apoptosis. The light green colour of control cells after $48 \mathrm{~h}$ can be explained by the fact that cells had already used most of the components of the medium and, as a result, their viability was decreased. This correlates to the intensity of fluorescence in apoptotic cells. This staining confirmed our conclusion that serum starvation induces apoptosis in ThESC cells. These results correlate to the data obtained using the MTT assay and phase-contrast microscopy. The serum deprivation of ThESC cells for various durations resulted in characteristics typical of apoptosis, such as chromatin condensation, chromosomal defragmentation, and nuclear shrinkage. Although DNA fragmentation has been considered a hallmark of apoptosis, there is a consensus on the dispensability of this characteristic in certain cell types under defined conditions $(33,34)$. Conceivably, the regulation and kinetics of DNA degradation in the fibroblast-like cell line may be different from that of thymocyte $(35,36)$ or lymphocyte $(20,37)$ models. 
The serum-deprived cells also demonstrated several other characteristic morphological features of apoptotic cell death (20), including rounding, loss of cell-to-cell contact, cellular condensation, and the preservation of membrane integrity and organelle structures. Our findings are consistent with studies using other cell lines (20, 21, 28). However, unlike the study of G. V. Kulkarni and C. A. G. McCulloch, we detected DNA fragmentation. The previously described apoptotic changes correlate with the intensity of red-orange fluorescence observed by EB/AO staining. Our results agree with previous studies that suggest that serum starvation causes the release of cytochrome $\mathrm{c}$ from the mitochondria with a loss of mitochondrial membrane potential (38). Thus, our findings suggest a hypothesis by which serum deprivation results in the apoptotic death of ThESC cells through mitochondrial pathways. If our assumption is correct, the results would be consistent with previous studies demonstrating that the release of cytochrome c activates caspase- 9 , which then activates caspase- 3 and leads to DNA fragmentation $(39,40,41)$. This pathway represents the classic mitochondrial or intrinsic pathway to apoptosis. Similar results have been obtained in other studies $(42,43)$. Serum deprivation may also be associated with the activation of caspase- 8 , which represents a key player in the extrinsic or death receptor-mediated pathway of apoptosis (44). Although this and other similar factors have not yet been investigated in ThESC cells, the serum deprivation of ThESC cells could also result in the activation of the extrinsic pathway of apoptosis. Further studies are needed to delineate the exact mechanism and pathway of apoptosis in serum-starved ThESC cells

\section{ACKNOWLEDGMENTS}

This study was funded with the financial and material support of the Faculty of Medical Sciences in Kragujevac as part of the junior project: 'Efekat Raloksifena na citotoksičnost Metotreksata i Miotreksata in vitro" number JП02/11 and project titled "Preklinička ispitivanja bioaktivnih supstanci (PIBAS)", registry number 41010 .

\section{REFERENCES}

1. Nowak RA. Novel therapeutic strategies for leiomyomas: targeting growth factors and their receptors. Environmental Health Perspectives. 2000; Volume 108 , Supplement 5, pages 849-853

2. Strinic Tomislav et al. Uterine Artery Embolisation as Nonsurgical Treatment of Uterine Myomas. Obstet Gynecol. 2011; Article ID 489281, 4 pages doi:10.5402/2011/489281

3. Victor Gomel MD and Andrew I. Brill MD Reconstructive and Reproductive Surgery in Gynecology, First Edition. 2010; Elizabeth L. Taylor, Elizabeth A. Pritts, William H. Parker, and David L. Olive.; chapter 19, page 326 (doi: 10.3109/9781841847573)
4. Stewart EA. Uterine fibroids. Lancet. 2001; 357(9252):293-8.

5. Flake GP, Andersen J, Dixon D. Etiology and pathogenesis of uterine leiomyomas: a review. Environmental Health Perspectives. 2003; 111:1037-1054. http:// dx.doi.org/10.1289/ehp.5787

6. Nowak RA Identification of new therapies for leiomyomas: what in vitro studies can tell us. Clin Obstet Gynecol. 2001; 44(2):327-34.

7. Shannon K. Laughlin, Jane C. Schroeder, Donna Day Baird. New Directions in the Epidemiology of Uterine Fibroids. Semin Reprod Med. 2010; 28(3):204-17

8. Krikun G. et al. A novel immortalized human endometrial stromal cell line with normal progestational response._Endocrinology, 2004; vol. 145 no. 5 2291-2296

9. Gerhard Gstraunthaler. Alternatives to the Use of Fetal Bovine Serum: Serum-free Cell Culture. Altex, 2003; volume 20, issue 4, pages 275-281

10. Annemarie Honegger and Rene E. Humbel. Insulinlike Growth Factors I and I1 in Fetal and Adult Bovine Serum. The Journal of Biological Chemistry, 1986; Vol. 261, No 2, pp. 569-575

11. Edward G. Hayman, Michael D. Pierschbacher, Shintaro Suzuki, Erkki Ruoslahti. Vitronectin-A major cell attachment-promoting protein in fetal bovine serum. Cell biology, 1983; Vol. 80, pp. 4003-4007

12. Lin Chen, Simon J. T. Mao, and William J. Larsen. Identification of a Factor in Fetal Bovine Serum That Stabilizes the Cumulus Extracellular Matrix. The Journal of Biological Chemistry, 1992; Vol. 267, No. 17, Issue of June 15, pp. 12380-12386

13. J.R. Dobrinsky, L.A. Johnson and D. Rath. Development of a Culture Medium (BECM-3) for Porcine Embryos: Effects of Bovine Serum Albumin and Fetal Bovine Serum on Embryo Development. Biology of Reproduction. 1996; vol. 55 no. 5 1069-1074

14. Stephan J. Reshkin. et al. Phosphoinositide 3-Kinase Is Involved in the Tumor-specific Activation of Human Breast Cancer Cell $\mathrm{Na} / \mathrm{H}$ Exchange, Motility, and Invasion Induced by Serum Deprivation. The Journal of Biological Chemistry. 2000; 25;275(8):5361-9.

15. Mara Fiorani, Orazio Cantoni, Andrea Tasinato, Daniel Boscoboinik, Angelo Azzi. Hydrogen peroxide-and fetal bovine serum-induced DNA synthesis in vascular smooth muscle cells: positive and negative regulation by protein kinase $\mathrm{C}$ isoforms. Biochim Biophys Acta. 1995; 19;1269(1):98-104.

16. Barbara A. Christy, Lester F. Lau, and Daniel Nathans. A gene activated in mouse $3 \mathrm{~T} 3$ cells by serum growth factors encodes a protein with "zinc finger" sequences (transcription factors/serum response element). PNAS. 1988; vol. 85 no. 21 7857-7861

17. Chang-Qing Zhao, Da Liu, Hai Li, Lei-Sheng Jiang and Li-Yang Dai. Interleukin-1 $\beta$ enhances the effect of serum deprivation on rat annular cell apoptosis. Apoptosis. 2007;12(12):2155-61. 
18. Esther Potier, Elisabeth Ferreira, Alain Meunier, Laurent Sedel, Delphine Logeart-Avramoglou, and Hervé Petite. Prolonged Hypoxia Concomitant with Serum Deprivation Induces Massive Human Mesenchymal Stem Cell Death. Tissue Eng. 2007;13(6):1325-31.

19. Barbara Ahlemeyer, Anja Möwes, Josef Krieglstein. Inhibition of serum deprivation- and staurosporineinduced neuronal apoptosis by Ginkgo biloba extract and some of its constituents. Eur J Pharmacol. 1999; 19;367(2-3):423-30.

20. G. V. Kulkarni and C. A. G. McCulloch. Serum deprivation induces apoptotic cell death in a subset of Balb/c 3T3 fibroblasts. J Cell Sci. 1994;107(Pt 5):1169-79.

21. Weiquan Zhu, Jinghai Chen, Xiangfeng Cong, Shengshou $\mathrm{Hu}$, Xi Chen. Hypoxia and Serum DeprivationInduced Apoptosis in Mesenchymal Stem Cells. Stem Cells. 2006; 24(2):416-25.

22. Graciela Fuertes, Jos'e Javier Mart'in De Llano, Adoraci'on Villarroya, A. Jennifer Rivett and Erwin Knecht. Changes in the proteolytic activities of proteasomes and lysosomes in human fibroblasts produced by serum withdrawal, amino-acid deprivation and confluent conditions. Biochem J. 2003; 375(Pt 1): 75-86.

23. W.A. Kues, M. Anger, J.W. Carnwath, D.Paul, J.Motlik, and H. Niemann. Cell Cycle Synchronization of Porcine Fetal Fibroblasts: Effects of Serum Deprivation and Reversible Cell Cycle Inhibitors. Biology of Reproduction. 2000; vol. 62 no. 2 412-419

24. Rosario Maroto and J. Regino Perez-Polo. BCL-2-Related Protein Expression in Apoptosis: OxidativeStress Versus Serum Deprivation in PC12 Cells. J Neurochem. 1997; 69(2):514-23.

25. Hee-Yong Kim, Mohammed Akbar, Audrey Lau, and Lisa Edsall. Inhibition of Neuronal Apoptosis by Docosahexaenoic Acid (22:6n-3) Role Of Phosphatidylserine In Antiapoptotic Effect. J Biol Chem. 2000; 275(45):35215-23.

26. Hans-Peter Gerber. et al. Vascular Endothelial Growth Factor Regulates Endothelial Cell Survival through the Phosphatidylinositol 3-Kinase/Akt Signal Transduction Pathway. J Biol Chem. 1998; 273(46):30336-43.

27. Supriya Jayadev et al. Role For Ceramide In Cell Cycle Arrest. The Journal of Biological Chemistry. 1995; 270, $2047-2052$.

28. Alicia A Goyeneche, Jacquelyn M Harmon and Carlos M Telleria. Cell death induced by serum deprivation in luteal cells involves the intrinsic pathway of apoptosis. Reproduction. 2006; 131(1):103-11.

29. Takamatsu Manabu, Fujita Tsunenori, and Hotta Hak. Suppression Of Serum Starvation-Induced Apoptosis By Hepatitis C Virus Core Protein. Kobe J. Med.Sci. 2001; 47,97/112

30. Kummer J. L., Rao P. K., and Heidenreich K. A. Apoptosis induced by withdrawal of trophic factors is mediated by p38 mitogen-activated protein kinase. Journal of Biological Chemistry. 1997; 272, 20490-20494.
31. Xia, Z., Dickens, M., Raingeaud, J., Davis, R. J., and Greenberg, M. E. Opposing effects of ERK and JNKp38 MAP kinases on apoptosis. Science. 1995; Vol. 270 no. 5240 pp. $1326-1331$

32. Chantal J. Schamberger, Christopher Gerner, Christa Cerni. Caspase-9 plays a marginal role in serum starvationinduced apoptosis. Exp Cell Res. 2005; 302(1):115-28.

33. Cohen, G. M., Sun, X.-M., Snowden, R. T., Dinsdale, D. and Skilleter, D. N. Key morphological features of apoptosis may occur in the absence of internucleosmal DNA fragmentation. Biochem J. 1992; 286(Pt 2): 331-334.

34. Collins, R. J., Harmon, B. V., Gobe, G. C. and Kerr, J. F. Internucleosomal DNA cleavage should not be the sole criterion for identifying apoptosis. Int. J. Rad. Biol. 1992; Vol. 61, No. 4, Pages 451-453

35. Cohen, J. J. and Duke, R. C. Glucocorticoid activation of calcium dependent endonuclease in thymocyte nuclei leads to cell death. J Immunol. 1984; 132(1):38-42.

36. Yonish-Rouach, E., Resnitzky, D., Lotem, J., Sachs, L., Kimchi, A. and Oren, M. Wild-type p53 induces apoptosis of myeloid leukaemic cells that is inhibited by interleukin-6. Nature. 1991; 352(6333):345-7.

37. Colotta, F., Polentarutti, N., Sironi, M. and Mantovani, A. Expression and involvement of c-fos and c-jun protooncogenes in programmed cell death induced by growth factor deprivation in lymphoid cell lines. J Biol Chem. 1992; 267(26):18278-83.

38. Irma Charles. et al. Serum Deprivation Induces Apoptotic Cell Death of Transformed Rat Retinal Ganglion Cells via Mitochondrial Signaling Pathways. Invest Ophthalmol Vis Sci. 2005; 46(4):1330-8.

39. Li Y, Schlamp CL, Nickells RW. Experimental induction of retinal ganglion cell death in adult mice. Invest Ophthalmol Vis Sci. 1999; 40(5):1004-8.

40. Liu X, Kim CN, Yang J, Jemmerson R, Wang X. Induction of apoptotic program in cell-free extracts: requirement for dATP and cytochrome c. Cell. 1996; 86(1):147-57.

41. Liu X, Zou H, Slaughter C, Wang X. DFF, a heterodimeric protein that functions downstream of caspase-3 to trigger DNA fragmentation during apoptosis. Cell. 1997; 89(2):175-84.

42. Xinjianp Peng, Takeshmi Aruo, Hiroyam Atsuo, Shigekti Akekida, and Jun Deguchi. Serum Deprivation-Induced Apoptosis in Cultured Porcine Granulosa Cells Is Characterized by Increased Expression of p53 Protein, Fas Antigen and Fas Ligand and by Decreased Expression of PCNA. Endocr J. 1998; 45(2):247-53.

43. Gustincich S. and Schneider C. Serum deprivation response gene is induced by serum starvation but not by contact inhibition. Cell Growth Differ. 1993; 4(9):753-60.

44. Zhang B, Hirahashi J, Cullere X, Mayadas TN. Elucidation of molecular events leading to neutrophil apoptosis following phagocytosis: cross talk between caspase 8 , reactive oxygen spe cies, and MAPK/ERK activation. J Biol Chem. 2003; 278(31):28443-54. 